\title{
Pengaruh Praktik Internet Financial Reporting (Ifr) Terhadap Nilai Pasar Perusahaan (Studi Empiris Pada Perusahaan Lq45 Yang Terdaftar Di Bursa Efek Indonesia)
}

\author{
Dian Annisa Putri ${ }^{1}$, Khairunnisa Harahap ${ }^{2}$, Akmal Huda Nasution ${ }^{3}$ \\ Universitas Negeri Medan \\ dianannisaputri391@gmail.com ${ }^{1}$, nisaharahap@yahoo.com ${ }^{2}$
}

\begin{abstract}
The problem in this research is the advancement of technology to make the company that makes official website in disclosing financial and nonfinancial information, Internet change the presentation of company information. This research aims to determine the influence of Internet Financial Reporting practices on the market value of LQ45 decisively company listed on the Indonesia Stock Exchange (IDX) period 2018. The population of this research is 50 LQ45 companies listed on the Indonesia Stock Exchange (IDX) period 2018. The sampling method used is purposive sampling, with a sample number of 32 companies. The data analysis technique in this study is a double linear regression analysis. An independent variable is internet financial reporting. The research uses control variables i.e. EPS, Bvps, company size, profitability, liquidity, and leverage. The dependent variables in this study are the company's market value. The results in this study of internet financial reporting practices influenced the company's market value. Two control variables i.e. company size and profitability are influential to the company's market value. While the variable control eps, bvps, liquidity and leverage have no significant effect on the company's market value. The conclusion in this study is that internet financial reporting practices have significant effect on the company's market value. Variable size control firms and profitability have significant effect on the company's market value. However for variable control EPS, Bvps, liquidity, and leverage have no significant effect on the company's market value.
\end{abstract}

Keywords: Internet Financial Reporting, Company market value 


\section{Pendahuluan}

Internet (Inter-Network) melalui sistem world wide web (www) saat ini telah menjadi bagian hidup sehari-hari dari aktivitas manusia. Organisasi bisnis telah banyak memanfaatkan sistem word wide web ini untuk menunjang kegiatan bisnisnya. Bisnis e-commerce telah banyak bermunculan dan terjadi transformasi transaksi dari manual menjadi transaksi elektronik di dunia maya. Peningkatan teknologi komputer dan internet secara signifikan telah berdampak pada praktik komunikasi laporan keuangan di dunia (Rozak, 2012). Banyak perusahaan yang membuat website resmi untuk perusahaan dalam mengungkapkan informasi keuangan dan nonkeuangan, internet mengubah penyajian informasi perusahaan secara tradisional. Praktik pengungkapan informasi keuangan dan nonkeuangan yang menggunakan internet sebagai media nya disebut dengan Internet Financial Reporting.

Saat ini Internet Financial Reporting menjadi penting karena penyebaran geografis dari investor yang tinggal di berbagai negara, dan pengungkapan metode tradisional dengan menggunakan hardcopy memiliki kekurangan dimana terdapat keterbatasan waktu dalam penyampaiannya. Di era globalisasi sekarang ini, investor dan calon investor dapat berasal dari negara manapun, maka dengan menggunakan metode Internet Financial Reporting sangat berguna untuk mengungkapkan informasi karena informasi tersebut telah tersedia di website resmi perusahaan dan dapat diakses dimanapun dan kapanpun. Internet Financial Reporting juga membuat perusahaan menjadi lebih transparan, dengan informasi yang diberikan kepada pengguna laporan keuangan sehingga asimetri informasi antara manajemen dan investor dapat berkurang. (Adityawarman \& Khudri, 2018).

Pasar modal dikenal sebagai tempat bertemunya antara pihak yang memiliki kelebihan dana dan pihak yang membutuhkan dana dengan memperjual belikan sekuritas. Sekuritas yang diperdagangkan di pasar modal adalah saham preferen, saham biasa, hak dan obligasi konvertibel. Kebutuhan akan dana ini semakin besar jika kegiatan perusahaan mengalami peningkatan. Menerbitkan saham merupakan salah satu alternatif perusahaan dalam memperoleh dana tambahan dari pihak luar. Saham juga dinilai mampu memberikan tingkat keuntungan yang menarik bagi investor, karena saham merupakan sekuritas yang paling banyak diminati investor (Gurusinga, 2013).

Salah satu teknik penilaian kinerja perusahaan dapat dilakukan dengan nilai pasar perusahaan. Nilai pasar perusahaan merupakan suatu penilaian kinerja keuangan perusahaan dengan menilai seberapa besar nilai tambah yang berhasil diberikan perusahaan kepada para investor. Berkaitan dengan penilaian pasar, nilai pasar hanya dapat dihitung pada perusahaan yang sudah go public dan terdaftar di pasar modal. Dengan menggunakan nilai pasar perusahaan, diharapkan perusahaan dapat mengukur tingkat kemakmuran dari nilai perusahaan.

Nilai pasar, sering disebut kurs adalah harga yang terjadi dari proses tawar-menawar di pasar saham. Nilai ini hanya bisa ditentukan jika saham perusahaan dijual di pasar saham (Yulius Jogi, 2016). Nilai pasar digunakan sebagai indikator untuk mengukur mahal murahnya suatu saham, ukuran prestasi perusahaan yang paling lengkap bagi para pemegang saham, serta dapat membantu investor dalam mencari saham yang memiliki potensi keuntungan yang besar sebelum melakukan investasi .

Dengan adanya Internet Financial Reporting, investor dapat lebih cepat mengakses informasi keuangan perusahaan sebagai dasar pembuatan keputusan. Lebih lanjut tindakan investor akan tercermin pada pergerakan saham di bursa. Semakin banyak informasi yang tersedia dan semakin cepat informasi itu tersedia akan mempemudah investor dalam mengevaluasi kembali keputusannya dalam berinvestasi. Informasi tersebut akan menciptakan penawaran dan permintaan oleh para investor yang berujung pada transaksi perdagangan saham yang meningkat maka harga saham perusahaan akan meningkat yang secara langsung berkontribusi pada nilai pasar perusahaan (Novitasari, 2017)

Hasil penelitian dari (Khikmaawati.Insani \& Agustina.Lina, 2015) dengan judul analisis rasio keuangan terhadap pelaporan keuangan melalui internet pada website perusahaan dari penelitian tersebut dapat disimpulkan bahwa aktivitas berpengaruh positif signifikan terhadap kualitas pelaporan keuangan melalui internet. Likuiditas berpengaruh negatif signifikan terhadap kualitas pelaporan keuangan melalui internet. Sedangkan profitabilitas dan leverage tidak berpengaruh signifikan terhadap kualitas pelaporan keuangan melalui internet.

Hasil penelitian dari (Rozak, 2012) dengan judul pengaruh tingkat profitabilitas, ukuran perusahaan, kepemilikan saham oleh publik, leverage dan kelompok industri terhadap tingkat internet financial reporting (ifr) dari penelitian tersebut dapat disimpulkan bahwa variabel tingkat 
profitabilitas dan ukuran perusahaan berpengaruh signifikan terhadap tingkat internet financial reporting (ifr) sementara variabel kepemilikan saham oleh publik, leverage dan kelompok industri tidak berpengaruh secara signifikan terhadap tingkat internet financial reporting (ifr).

Hasil penelitian dari (Puspitaningrum \& Atmini, 2012) dengan judul mekanisme corporate governance dan level dari internet financial reporting dari penelitian tersebut dapat disimpulkan bahwa frekuensi rapat komite audit berpengaruh positif terhadap internet financial reporting sementara kepemilikan manajerial, blockholder ownership, komisioner independen, dan kompetensi komite audit tidak berpengaruh terhadap internet financial reporting.

Hasil penelitian dari (Reskino \& Sinaga, 2017) menunjukkan bahwa ukuran perusahaan berpengaruh positif terhadap pengungkapan internet financial reporting sementara leverage, profitabilitas, likuiditas tidak berpengaruh signifikan pengungkapan internet financial reporting terhadap perusahaan sektor properti, real estate dan konstruksi bangunan.

Tujuan dari penelitian ini adalah untuk mengetahui pengaruh praktik internet financial reporting terhadap nilai pasar perusahaan. Fokus dalam penelitian ini adalah perusahaan LQ45 yang terdaftar di Bursa Efek Indonesia di tahun 2018. Dalam penelitian ini menunjukkan bahwa terdapat pengaruh yang signifikan antara praktik internet financial reporting terhadap nilai pasar perusahaan.

\section{Landasan Teori Dan Pengembangan Hipotesis Teori Agensi}

Teori keagenan dapat dikatakan sebagai suatu dasar teori yang membuat model proses kontrak antara dua orang atau lebih. Perusahaan mempunyai banyak kontrak, misalnya kontrak kerja antara perusahaan dengan manajernya dan kontrak pinjaman antara perusahaan dengan krediturnya. Prinsip teori ini menyatakan adanya sebuah kontrak antara manajemen (agent) dengan investor (principal), hubungan agensi ada ketika salah satu pihak (principal) menyewa pihak lain (agent). Dorongan tersebut ditunjukkan pada literatur sebagai alat penggerak yang dipakai untuk mengurangi asimetri informasi antara agen dan prinsipal. Teori keagenan timbul karena adanya perbedaan kepentingan sehingga masing-masing pihak berusaha memperbesar keuntungan bagi dirinya sendiri (Rizki \& Ikhsan, 2018).

\section{Teori Sinyal}

Teori sinyal mengemukakan mengenai bagaimana perusahaan seharusnya memberikan sinyal kepada para pengguna laporan keuangan. Sinyal yang dimaksudkan adalah berupa informasi mengenai apa yang sudah dikerjakan oleh manajemen untuk merealisasikan keinginan pemilik. Perusahaan yang yakin memiliki prospek yang positif akan cenderung lebih banyak menyampaikan berita itu kepada investor. Sinyal-sinyal yang di berikan dapat di sampaikan melalui website pribadi perusahaan agar dapat di lihat oleh siapa saja dan agar memperoleh informasi yang sama, sinyal yang diberikan juga dapat menjelaskan kelebihan perusahaan tersebut dibanding dengan perusahaan lainnya (Rizki \& Ikhsan, 2018).

\section{Teori Pasar Efisien}

Konsep pasar efisien pertama kali dikemukakan dan dipopulerkan oleh (Fama, 1970). Dalam konteks ini yang dimaksud dengan pasar adalah pasar modal (capital market) dan pasar uang. Suatu pasar dikatakan efisien apabila tidak seorangpun, baik investor individu maupun investor institusi, akan mampu memperoleh return tidak normal (abnormal return), setelah disesuaikan dengan risiko, dengan menggunakan strategi perdagangan yang ada. Artinya, harga-harga yang terbentuk di pasar merupakan cerminan dari informasi yang ada atau "stock prices reflect all available information".

\subsection{Pengembangan Hipotesis}

\section{Pengaruh Praktik Internet Financial Reporting Terhadap Nilai Pasar Perusahaan}

Memaksimalkan nilai pasar perusahaan melalui harga sahamnya untuk meningkatkan kekayaan investor adalah tujuan manajemen keuangan perusahaan. Dalam rangka untuk mewujudkan hal ini terjadi, perusahaan harus memiliki kinerja yang baik dalam mengelola risiko perusahaan dan keuntungan sehingga nilai perusahaan dan kekayaan investor akan meningkat. Kekayaan pemegang saham akan meningkat karena pembagian dividen atau keuntungan modal yang berasal dari peningkatan harga saham. 
Informasi keuangan dan nonkeuangan diperlukan untuk mengetahui bagaimana perusahaan mengelola keuangan dalam setiap periode; oleh karena itu, informasi keuangan dan nonkeuangan harus diterbitkan sehingga investor selalu dapat menilai nilai pasar perusahaan melalui harga saham. Nilai pasar perusahaan dipengaruhi oleh faktor-faktor seperti earning per share, book value per share, ukuran perusahaan, leverage, likuiditas, dan profitabilitas (Amanah, Atmanto, \& Azizah, 2014; Pujo Gunarso, 2014).

Dengan melakukan praktik IFR melalui website perusahaan, maka investor memiliki akses resmi ke situs perusahaan mengenai informasi dan berita perusahaan yang telah dirilis. Keberadaan praktik IFR membuat informasi keuangan dan nonkeuangan yang relevan tersedia dan dapat berkontribusi pada proses pengambilan keputusan.

Penelitian ini bertujuan untuk mengetahui apakah adanya keterbukaan informasi melalui praktik IFR yang mencerminkan harga saham menurut hipotesis pasar efisien, dimana praktik-praktik IFR mempunyai pengaruh pada nilai pasar perusahaan pada saat laporan keuangan di publikasi.

$\mathbf{H}_{\mathbf{1}}=$ Internet Financial Reporting berpengaruh terhadap Nilai Pasar Perusahaan.

\section{Gambar 2.1}

Model Penelitian

Variabel Independen

Variabel Dependen

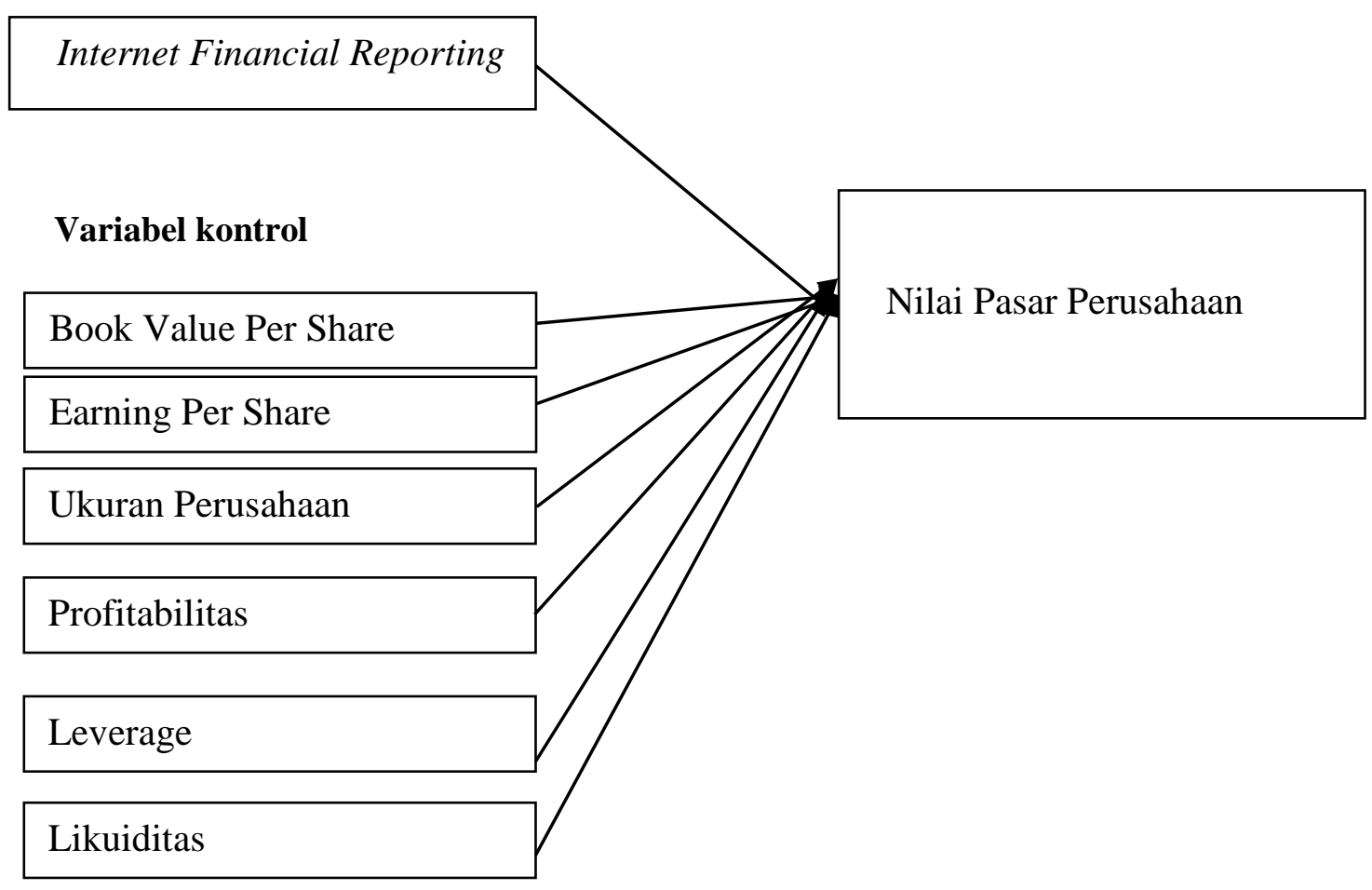

\section{Metode Penelitian}

\subsection{Populasi Dan Sampel Penelitian}

Populasi dalam penelitian ini adalah perusahaan LQ45 yang terdaftar di Bursa Efek Indonesia Populasi dalam penelitian ini adalah perusahaan LQ45 yang tercatat (go public) di Bursa Efek Indonesia (BEI) untuk tahun 2017 dan 2018. Perusahaan LQ45 yang tercatat di BEI digunakan sebagai populasi karena perusahaan yang terdaftar adalah perusahaan dari berbagai bidang. Tahun penelitian ini dilakukan pada tahun 2018. Alasan dalam pemilihan tahun tersebut karena penelitian ini dilaksanakan pada awal tahun 2019. Penelitian ini menggunakan non-random (nonprobability sampling) dimana sampel dipilih tidak didasarkan pada kemungkinan acak. Metode yang digunakan adalah purposive sampling, dimana pilihan sampel berdasarkan kriteria yang telah ditentukan. 
Tabel 3.1

Pemilihan Sampel

\begin{tabular}{lc} 
Kriteria Sampel & Jumlah \\
\hline Populasi perusahaan lq45 yang terdaftar di BEI pada tahun 2018 & 50 \\
Perusahaan yang mengalami perubahan selama februari-agustus 2018 & $(10)$ \\
Perusahaan yang menggunakan mata uang dollar & $(7)$ \\
Perusahaan yang laporan keuangannya tidak dapat diakses & $(1)$ \\
Perusahaan yang dijadikan sebagai sampel & $\mathbf{3 2}$ \\
\hline
\end{tabular}

Dari tabel diatas terdapat sebanyak 50 perusahaan lq45 yang terdaftar selama tahun 2018 di Bursa Efek Indonesia (Indonesia Stock Exchange). Sebanyak 10 perusahaan berada di posisi yang tidak konsisten dalam penempatan perusahaan yang terdaftar di indeks lq45. Sebanyak 7 perusahaan yang terdaftar di Bursa Efek Indonesia (Indonesia Stock Exchange) menampilkan mata uang asing yaitu berupa mata uang dollar dalam penyajian laporan keuangannya. Sementara ada 1 perusahaan yang menerbitkan laporan keuangannya di Bursa Efek Indonesia (Indonesia Stock Exchange) namun tidak dapat diakses. Maka setelah dilakukan kriteria sampel dalam penelitian ini sebanyak 32 perusahaan di jadikan sampel penelitian.

\subsection{Definisi Operasional Dan Pengukuran Variabel}

\subsubsection{Nilai Pasar Perusahaan}

Memaksimalkan nilai pasar perusahaan melalui harga sahamnya untuk meningkatkan kekayaan investor adalah tujuan manajemen keuangan perusahaan. Yang diukur menggunakan rumus harga saham yang beredar pada pasar modal dikali dengan saham yang beredar (Ahmed, Tahat, Burton, \& Dunne, 2015; Livant \& Segal, 2000)

Nilai Pasar $=$ Harga Saham yang Beredar $\mathrm{x}$ Saham yang beredar.

\subsubsection{Internet Financial Reporting}

Untuk menemukan nilai pengungkapan internet financial reporting penelitian ini menggunakaan ohlson model dimana ohlson model ini digunakan untuk mengetahui sejauh mana perusahaan mengungkapkan internet financial reporting (Ota, 2002). Pengukuran kualitas pengungkapan laporan di internet menggunakan skor konten dalam indeks yang disusun oleh (Boubaker, Lakhal, \& Nekhili, 2011) berdasarkan literatur yang telah dikembangkan oleh (Debreceny et al., 2002; Spanos, 2006; Xiao et al., 2004) maka item-item indeks dalam Internet Financial Reporting (IFR) memiliki 101 jumlah item yang terbagi menjadi general and investor-related information (25 item), financial information (27 item), corporate social responsibility (6 item), user friendly and technology (26 item), timeliness (7 item). Diberi skor 1 apabila mengungkapkan dan skor 0 apabila tidak diungkapkan.

$$
\mathrm{IRI}=\frac{\text { Total item yang diungkapkan }}{\text { Total item yang mungkin diungkapkan }}
$$

\subsubsection{Variabel Kontrol}

Variabel kontrol adalah variabel yang dikendalikan atau dibuat konstan sehingga pengaruh variabel independen terhadap dependen tidak dipengaruhi oleh faktor luar yang tidak diteliti (Sugiyono,1999:33). Dalam penelitian ini adalah earning per share, book value per share, ukuran perusahaan, profitabilitas, leverage, likuiditas.

\subsection{Metode Analisis Data}

Analisis Regresi berganda digunakan untuk menguji pengaruh dua atau lebih variabel independen terhadap variabel dependen (Ghozali, 2011:96). Analisis regresi berganda dalam penelitian ini digunakan untuk menguji pengaruh pelaporan perusahaan berbasis internet menggunakan model Ohlson karena model tersebut telah banyak digunakan oleh peneliti-peneliti lain 
untuk melihat pengaruh level IFR sebagai variabel independen. Variabel dependen nilai pasar perusahaan, menggunakan empat variabel kontrol dalam penelitian ini yaitu earning per share, book value per share, ukuran perusahaan, likuiditas, profitabilitas, dan leverage.

Model regresi yang dikembangkan untuk penelitian ini adalah :

$\operatorname{lnMV}_{\mathrm{i}, \mathrm{t}}=\alpha_{0}+\alpha_{1} \mathrm{IFR}_{\mathrm{i}, \mathrm{t}}+\alpha_{2} \mathrm{BVPS}_{\mathrm{i}, \mathrm{t}}+\alpha_{3} \mathrm{EPS}_{\mathrm{i}, \mathrm{t}}+\alpha_{4} \operatorname{lnSIZE}_{\mathrm{i}, \mathrm{t}}+\alpha_{5} \mathrm{ROA}_{\mathrm{i}, \mathrm{t}}+\alpha_{6} \mathrm{LIQ}_{\mathrm{i}, \mathrm{t}}+\alpha_{7} \mathrm{LEV}_{\mathrm{i}, \mathrm{t}}+\varepsilon_{\mathrm{i}, \mathrm{t}}$

LNMV : Nilai logaritma pada nilai pasar perusahaan pada akhir bulan ke empat setiap tahun, publikasi laporan keuangan tahunan

IFR : Nilai pengungkapan Internet Financial Reporting pada The Internet Disclosure index

BVPS : Nilai buku pada setiap akhir tahun pada laporan tahunan

EPS : Nilai earnings per share perusahaan pada akhir tahun laporan keuangan yang dikalkulasikan berdasarkan keuntungan yang telah dipotong pajak

LNSIZE : Ukuran perusahaan yang berdasarkan perhitungan aset perusahaan pada setiap akhir tahun

ROA : profitabilitas perusahaan pada return on asset

LIQ : Likuiditas perusahaan berdasarkan current ratio

LEV : Leverage perusahaan pada debt to equity ratio

\section{Hasil Penelitian Dan Pembahasan}

\subsection{Statistik Deskriptif}

Statistik deskriptif memberikan gambaran atau deskripsi suatu data yang dilihat dari nilai ratarata (mean), standar deviasi, varian, maksimum, minimum, sum, range, kurtosis, dan skewness (kemencengan distribusi) (Ghozali, 2016). Jumlah sampel penelitian yang digunakan dalam penelitian ini adalah berjumlah 32 jumlah sampel penelitian.

Tabel 4.1

Hasil Statistik Deskriptif

Descriptive Statistics

\begin{tabular}{|l|r|r|r|r|r|}
\hline & $\mathrm{N}$ & Minimum & Maximum & \multicolumn{1}{c|}{ Mean } & Std. Deviation \\
\hline IFRit & 32 &, 50 &, 58 &, 5300 &, 02185 \\
BVPSit & 32 & 2,73 & 8,76 & 7,2210 & 1,23277 \\
EPSit & 32 & 4,05 & 2983,00 & 397,6331 & 551,39503 \\
LNSIZEit & 32 & 27,11 & 34,80 & 31,5722 & 1,76404 \\
ROAit & 32 &, 01 &, 47 &, 0953 &, 10294 \\
LIQit & 32 &, 09 & 5,28 & 1,8226 & 1,51533 \\
LEVit & 32 &, 19 & 11,06 & 2,2928 & 2,66909 \\
LNMVit & 32 & 29,36 & 34,08 & 31,6467 & 1,37736 \\
Valid N (listwise) & 32 & & & & \\
\hline
\end{tabular}

\subsection{Hasil Uji Regresi}

Analisis regresi pada dasarnya adalah studi mengenai ketergantungan dependen (terikat) dengan satu atau lebih variabel independen (variabel penjelas/bebas), dengan tujuan untuk mengestimasi dan/atau memprediksi rata- rata populasi atau nilai variabel dependen berdasarkan nilai variabel independen diketahui (Gujarati, 2003) dalam (Ghozali, 2016). Berikut merupakan hasil uji regresi penelitian:

Tabel 4.2

Hasil Uji Regresi

\begin{tabular}{clcc}
\hline \multirow{2}{*}{ Model } & & \multicolumn{2}{c}{ Unstandardized Coefficients } \\
\cline { 3 - 4 } & & B & Std. Error \\
\hline & (Constant) & $-2,208$ & 6,410 \\
& IFRit & 18,452 & 7,941 \\
& BVPSit &, 301 &, 177 \\
& EPSit &, 001 &, 000 \\
\hline
\end{tabular}




\begin{tabular}{lcc}
\hline LNSIZEit &, 660 &, 019 \\
ROAit & 9,024 & 1,973 \\
LIQit &,- 089 &, 084 \\
LEVit &,- 116 &, 017 \\
\hline
\end{tabular}

a.Dependent variable:LNMVit

Dari tabel analisis regresi linier berganda diatas, maka dapat diketahui rumus model persamaan regresi sebagai berikut :

LNMVit $=-2,208+18,452$ IFRit + 0,301BVPSit + 0,001EPSit + 0,660 LNSIZEit+ 9,024ROAit+(-0,116)LIQit+0,089LEVit+ git

\subsection{Hasil Uji Hipotesis}

\subsubsection{Uji Signifikansi Simultan (Uji f)}

Uji signifikansi simultan (Uji statistik f) digunakan untuk menguji besarnya pengaruh dari seluruh variabel penelitian secara bersama-sama atau simultan terhadap variabel dependen (Ghozali, 2016). Hasil pengujian uji signifikansi simultan (uji F) dalam penelitian ini ditunjukkan dalam tabel di bawah:

Tabel 4.3 Hasil Uji F

\begin{tabular}{|c|c|c|c|c|c|c|}
\hline \multicolumn{7}{|c|}{ ANOVA $^{a}$} \\
\hline Model & & $\begin{array}{c}\text { Sum of } \\
\text { Squares }\end{array}$ & Df & Mean Square & $\mathrm{F}$ & ig. \\
\hline \multirow{3}{*}{1} & Regression & 40,081 & 7 & 5,384 & 7,793 &, $000^{\mathrm{b}}$ \\
\hline & Residual & 17,970 & 24 & ,749 & & \\
\hline & Total & 58,811 & 31 & & & \\
\hline
\end{tabular}

a. Dependent Variable: LNMVit

b. Predictors: (Constant),LEVit, EPSit, BVPSit, IFRit, ROAit, LNSIZEit, LIQit

\subsubsection{Uji Signifikansi Parameter Individual (Uji T)}

Uji parsial digunakan untuk mengetahui pengaruh masing-masing variabel independen terhadap variabel dependen (Ghozali, 2016). Berikut hasil pengujian untuk uji parsial (uji t):

\section{Tabel 6}

Hasil Uji T

Coefficients $^{\mathrm{a}}$

\begin{tabular}{|c|c|c|c|c|c|c|}
\hline \multirow[t]{2}{*}{ Mod } & & \multicolumn{2}{|c|}{ Unstandardized Coefficients } & Standardized & \multirow[t]{2}{*}{$\mathrm{t}$} & \multirow[t]{2}{*}{ Sig. } \\
\hline & & $B$ & Std. Error & Beta & & \\
\hline \multirow{8}{*}{1} & (Constant) & $-2,208$ & 6,410 & &,- 344 & ,734 \\
\hline & IFRit & 18,451 & 7,941 & 293 & 2,324 & ,029 \\
\hline & BVPSit & 301 & 177 & 270 & 1,705 & , 101 \\
\hline & EPSit & ,001 & ,000 & 295 & 1,859 & ,075 \\
\hline & LNSIZEit & 660 & ,119 & ,846 & 5,528 & 000 \\
\hline & ROAit & 9,024 & 1,973 & ,674 & 4,573 & ,000 \\
\hline & LIQit & (089, & 170 & 098 & ,525 & 605 \\
\hline & LEVit &,- 116 & 084 &,- 226 & $-1,381$ & 180 \\
\hline
\end{tabular}

a. Dependent Variable: LNMVit

\subsection{Pembahasan}

Berdasarkan dari hasil pengujian SPSS dapat dinyatakan bahwa hipotesis dalam penelitian ini diterima. Karena hasil dari pengujian SPSS menunjukkan bahwa nilai $\mathrm{F}$ statistik sebesar 0,000. Artinya bahwa variabel IFR, EPS, BVPS, SIZE, ROA, LIQ dan LEV secara bersama-sama berpengaruh terhadap variabel market value. Konstanta negatif umumnya terjadi jika ada rentang yang cukup jauh antara variabel independen dan variabel dependen. Konstanta negatif ini juga menandakan terjadinya perubahan jumlah pada variabel dependen. Berdasarkan uji hipotesis $\mathrm{t}$ 
untuk IFR menunjukkan nilai $\mathrm{T}_{\text {hitung }} 2,324>$ nilai $\mathrm{T}_{\text {tabel }} 2,042(2,324>2,042)$ dan nilai signifikansi $0,029<0,05$ yang berarti bahwa variabel pengungkapan IFR terbukti dan berpengaruh secara signifikan terhadap nilai pasar perusahaan. Dengan nilai koefisien sebesar 0,293, artinya secara statistik variabel IFR berpengaruh signifikan terhadap nilai pasar perusahaan.

Penelitian ini juga memasukkan beberapa variabel kontrol seperti book value of shareholder's equity (BVPS), earning per share (EPS), ukuran perusahaan (SIZE), profitabilitas (ROA), likuiditas (LIQ), dan leverage (LEV). Namun hanya variabel ukuran perusahaan (SIZE) dan profitabilitas (ROA) yang memiliki pengaruh signifikan terhadap nilai pasar perusahaan.

\section{Kesimpulan, Keterbatasan, Dan Saran 5.1 Kesimpulan}

Berdasarkan hasil analisis penelitian dapat dibuktikan bahwa internet financial reporting (IFR) berpengaruh terhadap nilai pasar perusahaan. Hasil ini menunjukkan bahwa ketika perusahaan melakukan praktik pengungkapan informasi keuangan maupun non keuangan yang dikenal dengan internet financial reporting memberikan pengaruh signifikan pada nilai pasar perushaan karena investor menggunakan informasi yang diungkapkan di website perusahaan untuk menilai perusahaan. Sementara untuk variabel kontrol pada uji $\mathrm{T}$ menunjukkan bahwa hanya ukuran perusahaan (SIZE) dan profitabilitas (ROA) yang menunjukkan nilai signifikan dan berpengaruh terhadap nilai pasar perusahaan. Namun untuk variabel kontrol book value per share (BVPS), earning per share (EPS), likuiditas (LIQ) dan leverage (LEV) tidak terbukti dan tidak berpengaruh secara signifikan terhadap nilai pasar perusahaan.

\subsection{Keterbatasan}

Keterbatasan dalam penelitian ini adalah populasi yang digunakan merupakan perusahaan indeks yang digunakan bukanlah indeks terbaru dan dikarenakan belum ada standar resmi yang diberlakukan oleh Ikatan Akuntan Indonesia (IAI) sehingga belum banyak indeks resmi yang dapat digunakan oleh perusahaan untuk mengungkapkan pelaporan berbasis website.

\subsection{Saran}

Setelah penulis melakukan penelitian ini saran dalam penelitian ini adalah penulis menyarankan hendaknya Ikatan Akuntan Indonesia (IAI) menerbitkan standar akuntansi keuangan yang bertemakan tentang Internet Financial Reporting. Karena pengungkapan informasi keuangan dan non keuangan melalui internet yang dinamakan dengan Internet Financial Reporting masih bersifat mandatory disclosure atau pengungkapan sukarela. Sehingga setiap perusahaan dapat melakukan pengungkapan berbasis website sesuai dengan standar yang resmi diberlakukan oleh Ikatan Akuntan Indonesia (IAI).

\section{Daftar Pustaka}

Adityawarman, A., \& Khudri, T. B. . Y. (2018). The Impact of Internet Financial Reporting Practices on the Company's Market Value: A Study of Listed Manufacturing Companies in Indonesia. Advances in Economics, Business and Management Research (AEBMR), 55(Iac 2017), 48-53.

Ahmed, A. H., Tahat, Y. A., Burton, B. M., \& Dunne, T. M. (2015). The value relevance of corporate internet reporting: The case of Egypt. Advances in Accounting, 31(2), 188-196.

Amanah, R., Atmanto, D., \& Azizah, D. F. (2014). Pengaruh Rasio Likuiditas dan Rasio Profitabilitas Terhadap Harga Saham (Studi pada Perusahaan Indeks LQ45 Periode 2008-2012). Jurnal Administrasi Bisnis, 12(1), 1-10.

Boubaker, S., Lakhal, F., \& Nekhili, M. (2011). The determinants of web-based corporate reporting in France. Managerial Auditing Journal, 27(2), 126-155.

Debreceny, R., Gray, G. L., \& Rahman, A. (2002). The determinants of internet financial reporting. Journal of Accounting and Public Policy, 21(4-5), 371-394.

Fama, E. (1970). Efficient Capital Markets: A Review of Theory and Empirical Work. Stock Market Price Behavior, 383-417.

Gurusinga, F. M. (2013). Pengaruh Internet Financial Reporting Terhadap Frekuensi Perdagangan Saham dan Abnormal Return Pada Perushaan Manufaktur Yang Terdaftar Di Bursa Efek 
Indonesia. Skripsi :UNIMED, 2(SGEM2016 Conference Proceedings, ISBN 978-619-7105-16-2 / ISSN 1314-2704), 1-39.

Keliwon, K. B., Abdul Shukor, Z., \& Hassan, M. S. (2018). Measuring Internet Financial Reporing (IFR) Disclosure Strateg. Asian Journal of Accounting and Governance, 8(Special Issue), 7-24. https://doi.org/10.17576/ajag-2017-08si-02

Khikmaawati.Insani, \& Agustina.Lina. (2015). Analisis Rasio Keuangan Terhadap Pelaporan Keuangan Melalui Internet Pada Website Perusahaan. Accounting Analysis Journal, 2(1), 1-10.

Livant, J., \& Segal, D. (2000). The Calculation of Earning Per Share and Market Value of Equity: Should Common Stock Equivalents be Included?

Novitasari, S. (2017). Pengaruh Internet Financial Reporting Terhadap Nilai Perusahaan Studi Empiris Pada Perusahaan Listing di Bursa Efek Indonesia Tahun 2016. Skripsi: Universitas Sanata Dharma Yogyakarta.

Ota, K. (2002). A test of the Ohlson (1995) model: Empirical evidence from Japan. International Journal of Accounting, 37(2), 157-182.

Pujo Gunarso. (2014). Laba akuntansi, leverage, dan ukuran perusahaan terhadap harga saham di bursa efek indonesia. Jurnal Keuangan Dan Perbankan, 18(1), 63-71. Retrieved from http://jurnal.unmer.ac.id/index.php/jkdp/article/view/773

Puspitaningrum, D., \& Atmini, S. (2012). Corporate Governance Mechanism and the Level of Internet Financial Reporting: Evidence from Indonesian Companies. Procedia Economics and Finance, 2(Af), 157-166. https://doi.org/10.1016/s2212-5671(12)00075-5

Reskino, \& Sinaga, N. N. J. (2017). Kajian Empiris Internet Financial Reporting Dan Praktek Pengungkapan. Media Riset Akuntansi, Auditing Dan Informasi, 16(2), 161. https://doi.org/10.25105/mraai.v16i2.1643

Rizki, F., \& Ikhsan, A. E. (2018). Pengaruh Rasio Aktivitas , Risiko Sistemati , dan Tingkat Kepemilikan Saham Terhadap Internet Financial Reporting ( Studi Pada Perusahaan Manufaktur Yang Terdaftar Di Bursa Efek Indonesia Periode 2011-2015 ). Jurnal Ilmiah Mahasiswa Ekonomi Akuntansi, 3(3), 443-458.

Rozak, A. (2012). Pengaruh Tingkat Profitabilitas, Ukuran Perusahaan, Kepemilikan Saham Oleh Publik, Leverage dan Kelompok Industri Terhadap Tingkat Internet Financial Reporting (IFR). Jurnal Computech \& Bisnis, Vol. 6, No. 2, Desember 2012, 101-112 ISSN 2442-4943 PENGARUH, 6(2), 101-112.

Spanos, L. (2006). Corporate Reporting on the internet in a European emerging capital market: the Greek case. Cener of Financial Studies Department of Economics University of Athens, 302.

Wardhanie, N. S. (2012). Analisis Internet Financial Reporting Index; Studi Komparasi Antara Perusahaan High-tech dan Non High-tech di Indonesia. Jrak, 2(2), 287-300.

Xiao, J. Z., Yang, H., \& Chow, C. W. (2004). The determinants and characteristics of voluntary Internet-based disclosures by listed Chinese companies. Journal of Accounting and Public Policy, 23(3), 191-225. https://doi.org/10.1016/j.jaccpubpol.2004.04.002

Yulius Jogi, C. (2016). Kepemilikan manajeral: kebijakan hutang, kinerja dan nilai perusahaan. Jurnal Ekonomi Akuntansi, 201-218. https://doi.org/10.9744/JAK.9.1.PP. 1-8 ddddd 